\title{
Analisis Spasial Pengaruh Dinamika Suhu Muka Laut Terhadap Distribusi Curah Hujan di Sulawesi Utara
}

\author{
Febriany Florence Rey ${ }^{a, b^{*}}$, Seni H. J. Tongkukuta, Wandayantolis ${ }^{b}$ \\ aJurusan Fisika, FMIPA, Unsrat, Manado \\ bBadan Meteorologi Klimatologi dan Geofisika
}

\begin{tabular}{l}
\hline K A T A K U N C I \\
\hline Analisis spasial \\
Suhu muka laut \\
Curah hujan
\end{tabular}

KEYW OR D S

Spatial analysis

Sea surface temperature

Precipitation

A B S T R A K
Telah dilakukan analisis terhadap distribusi curah hujan yang
dipengaruhi oleh dinamika suhu muka laut untuk mengetahui hubungan
distribusi curah hujan dan dinamika suhu muka laut di Sulawesi Utara,
serta telah dibuat peta spasial hubungan distribusi curah hujan dengan
dinamika suhu muka laut menggunakan ArcMap 9.3. Analisis yang
dilakukan menggunakan data curah hujan bulanan selama 10 tahun dari
5 stasiun BMKG dan 10 pos hujan kerjasama di Sulawesi Utara, dan data
dinamika suhu muka laut berdasarkan nilai Indeks Osilasi Selatan dengan
metode korelasi. Hasil penelitian diperoleh nilai korelasi positif antara
0,50 hingga 0,90 terjadi pada periode tiga bulanan yaitu Agustus-
September-Oktober pada seluruh wilayah pengamatan.

A B S T R A C T

Analysis of the precipitation that caused by the dynamics of sea surface temperature has been made to find the correlation between the precipitation and the dynamics of sea surface temperature, with its spatial map of the correlation between precipitation and the dynamics of sea surface temperature using ArcMap 9.3. The analysis use the monthly rainfall data for 10 years from 5 BMKG Stations and 10 rain-gauge network in North Sulawesi, and Southern Oscillation Index monthly value using correlation method. The result of this research is the positive correlation between 1,50 to 0,90 occur in the period of August-SeptemberOctober.
AVAILABLE ONLINE

25 Februari 2014

\section{Pendahuluan}

Iklim merupakan kondisi fisis atmosfer di suatu wilayah yang luas dalam jangka waktu yang panjang. Iklim di suatu tempat dipengaruhi oleh letak lintang, lereng, ketinggian serta seberapa jauh jarak tempat tersebut dari perairan dan juga keadaan arus lautnya [1]. Hujan merupakan jatuhan berupa partikel-partikel air (hydrometeor) dengan diameter $0.5 \mathrm{~mm}$ atau lebih. Apabila jatuhan hydrometeor tersebut mencapai permukaan tanah maka disebut hujan, namun jika jatuhan tersebut tidak mencapai permukaan tanah maka disebut virga [2].
Di wilayah Indonesia kejadian curah hujan bisa terjadi pada semua musim baik pada musim penghujan, transisi, maupun musim kemarau. Pada kenyataannya kejadian ini tidak seragam terjadi di semua tempat mengingat wilayah Indonesia sangatlah luas dan bervariasi dalam faktor pembentuk hujan. Suhu muka laut merupakan faktor penting untuk iklim regional dan iklim global. Wilayah Indonesia yang terletak di sebelah barat Samudera Pasifik akan mengalami tekanan udara rendah akibat menghangatnya suhu muka laut di sekitarnya. Kondisi ini menyebabkan massa udara dari Pasifik akan mengalir ke wilayah Indonesia sehingga terjadi konvergensi massa udara yang

*Corresponding author: Jurusan Fisika FMIPA UNSRAT, Jl. Kampus Unsrat, Manado, Indonesia 95115; Email address: febriany.rey@bmkg.go.id Published by FMIPA UNSRAT (2014) 
kaya uap air, maka peluang terjadinya hujan di wilayah Indonesia menjadi semakin besar.

Sirkulasi Walker adalah sirkulasi zonal (timurbarat) sepanjang ekuator. Dinamakan Sirkulasi Walker sebagai penghargaan bagi Sir Gilbert Walker yang pada tahun 1920-an telah mengetahui adanya variasi tekanan atmosfer timur-barat sepanjang Samudera Pasifik. Tekanan jungkat-jungkit (seasaw) Walker disebut Osilasi Selatan. Intensitas sirkulasi Walker dikendalikan oleh variasi suhu muka laut di Samudera Pasifik bagian timur dan bagian barat. Perubahan dalam suhu muka laut menyebabkan kadar panas dari samudera dialihkan ke dalam atmosfer dalam bentuk perubahan tekanan atmosfer [3].

Sesuai dengan posisi Sulawesi Utara yang berdekatan dengan Samudera Pasifik di bagian timur, menyebabkan iklim Sulawesi Utara akan terpengaruh secara langsung jika suhu muka laut di Samudera Pasifik mengalami dinamika. Oleh karena itu perlu dilakukan analisis pengaruh dinamika suhu muka laut terhadap iklim khususnya curah hujan di beberapa wilayah di Sulawesi Utara.

Tulisan ini bertujuan menganalisa pengaruh dinamika suhu muka laut terhadap distribusi curah hujan di Sulawesi Utara dan membuat peta spasial hubungan distribusi curah hujan dengan dinamika suhu muka laut dalam bentuk nilai indeks osilasi selatan.

\section{Metode}

Data yang digunakan dalam penelitian ini adalah data curah hujan bulanan selama 10 tahun (2003 - 2012) diperoleh dari 15 pos hujan yang tersebar di Sulawesi Utara, yang terdiri dari 5 Stasiun BMKG yaitu: Stasiun Klimatologi Manado, Stasiun Meteorologi Sam Ratulangi, Stasiun Meteorologi Maritim Bitung, Stasiun Geofisika Tondano, Stasiun Meteorologi Naha dan 10 Pos Hujan kerjasama yaitu: Pos Hujan Kema I, Pos Hujan Modoinding, Pos Hujan Ratahan, Pos Hujan Tombatu, Pos Hujan Mongkonai, Pos Hujan Poigar, Pos Hujan Pinolosian, Pos Hujan Kotabunan, Pos Hujan Pinogaluman, Pos Hujan Tagulandang; dan data Indeks Osilasi Selatan yang menunjukkan dinamika suhu muka laut bulanan selama 10 tahun dari tahun 2003 - 2012, diambil dari arsip situs resmi Biro Meteorologi Australia (bom.gov.au).

Alat-alat yang digunakan dalam penelitian adalah ArcMap, dan Microsoft Office. ArcMap merupakan salah satu perangkat lunak Sistem Informasi Geografis dan Pemetaan yang telah dikembangkan oleh ESRI (Environmental System Research Institue), yang memiliki kemampuan untuk melakukan visualisasi, mengeksplorasi, menganalisis secara geografis, dan sebagainya. Microsoft Office digunakan untuk pengolahan basis data yang akan diintegrasikan dengan ArcMap 9.3.

Metode penelitian yang dilakukan berupa inventarisasi terhadap data curah hujan yang tercatat di Stasiun Klimatologi Kayuwatu Manado (BMKG) untuk setiap Stasiun BMKG yang melakukan pengamatan hujan (5 Stasiun BMKG) dan satu pos hujan kerjasama untuk setiap kabupaten / kota di Sulawesi Utara (10 pos). Selanjutnya data curah hujan bulanan diolah menggunakan perhitungan curah hujan tiga bulanan, dengan asumsi dinamika suhu muka laut yang berdasarkan Indeks Osilasi Selatan bulanan masih berpengaruh pada distribusi curah hujan pada rentang waktu satu sampai dua bulan kedepan.

Langkah-langkah kerja yang dilakukan pada penelitian ini adalah :

1. Melakukan inventarisasi data curah hujan dan indek osilasi selatan. Data curah hujan diurutkan secara horizontal mulai dari bulan Januari hingga Desember, tahun 2003 hingga 2012.

2. Dengan menggunakan metode tiga bulanan (lag tiga bulan), data curah hujan bulanan setiap lokasi misalnya untuk bulan DesemberJanuari-Februari (DJF) dirata-ratakan dan diperoleh nilai rata-rata curah hujan tiga bulanan DJF, bulan Januari-Februari-Maret (JFM), Februari-Maret-April (FMA), dst sampai bulan November-Desember-Januari (NDJ) tahun 2003-2012.

3. Dihitung koefisien korelasi antara SOI bulan Desember tahun 2003-2012 dan rata-rata curah hujan tiga bulanan pertama (DJF) tahun 2003-2012 untuk satu pos pengamatan curah hujan dan dilakukan untuk seluruh pos pengamatan curah hujan. Hal yang sama dilakukan untuk SOI bulan Januari sampai November dengan curah hujan tiga bulanan JFM sampai NDJ.

4. Setelah diperoleh nilai korelasi $r$ dari dinamika suhu muka laut dan curah hujan, nilai korelasi tersebut dikumpulkan menjadi satu tabel dalam program Microsoft Excel.

5. Nilai $r$ yang diperoleh dibuat dalam format tab delimited (*.txt) setiap lokasi untuk setiap tiga bulanan dari tahun 2003 - 2012 untuk dapat diolah lebih lanjut dengan perangkat lunak ArcMap 9.3.

6. Nilai korelasi $r$ dalam format (*.txt) dimasukkan ke dalam perangkat lunak ArcMap 9.3 yang telah diberikan data koordinat lintang dan bujur, dan dijalankan untuk menghasilkan peta spasial.

7. Legenda yang diberikan dalam peta spasial menunjukkan perbedaan nilai $r$ dengan memberikan klasifikasi warna yang disinkronkan dengan nilai $r$, baik $r$ yang bernilai positif maupun negatif.

8. Peta spasial kemudian diekspor ke dalam format gambar (*.jpeg) untuk dapat disajikan dalam format Microsoft Word.

9. Analisis spasial dilakukan untuk melihat tingkat korelasi antara SOI dan curah hujan untuk tiap tiga bulanan tahun 2003-2012 di Suawesi Utara 


\section{Hasil dan Pembahasan}

Dinamika suhu muka laut yang ditunjukkan oleh nilai Indeks Osilasi Selatan dalam penelitian diperoleh dari arsip situs resmi Biro Meteorologi Australia (Bureau Meteorology of Australia, BOM), dikorelasikan dengan curah hujan rata-rata tiga bulanan kemudian menghasilkan peta spasial. Peta spasial dibuat untuk mendapatkan gambaran secara visual kondisi curah hujan masing-masing wilayah yang dipengaruhi oleh Indeks Osilasi Selatan, yang dinyatakan dengan nilai korelasi $r$, seperti pada Gambar 1 dan 2.

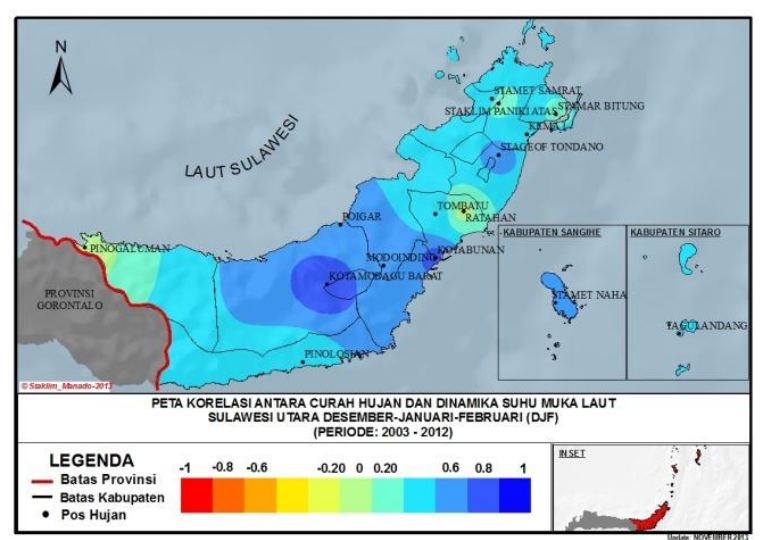

1(a)

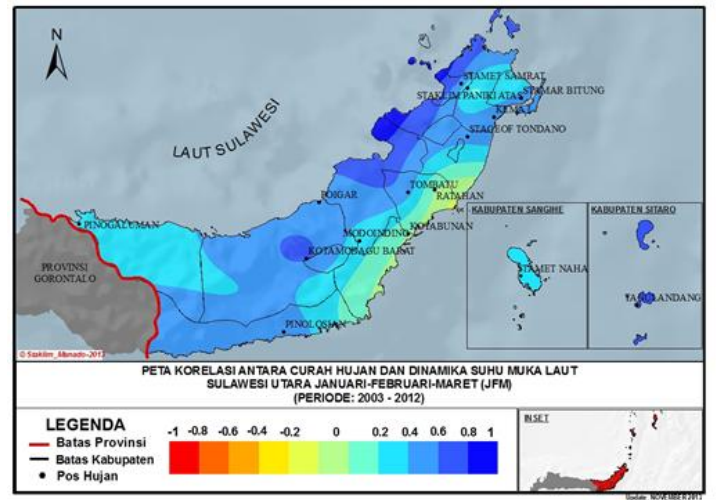

1(b)

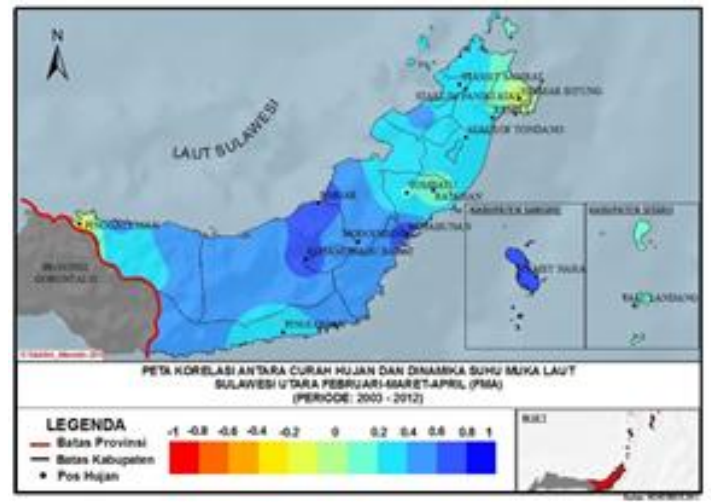

1(c)

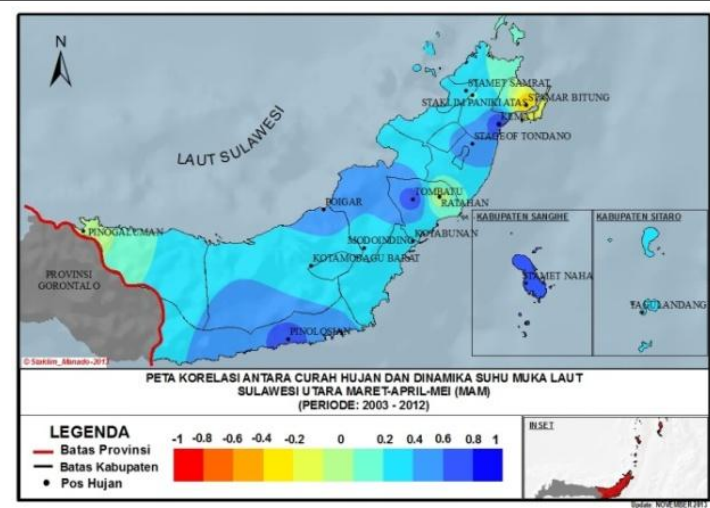

1(d)

Gambar 1 . Peta Spasial Korelasi Curah Hujan Dan Dinamika Suhu Muka Laut (a) DJF, (b) JFM, (c) FMA, (d) MAM periode 2003-2012.

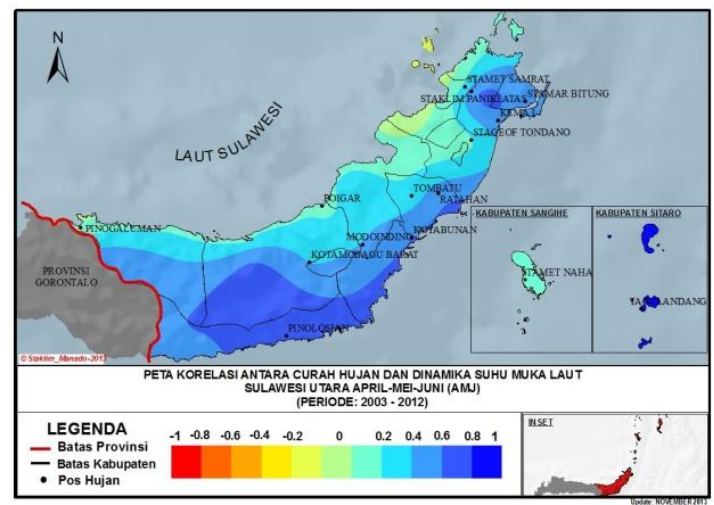

(a)

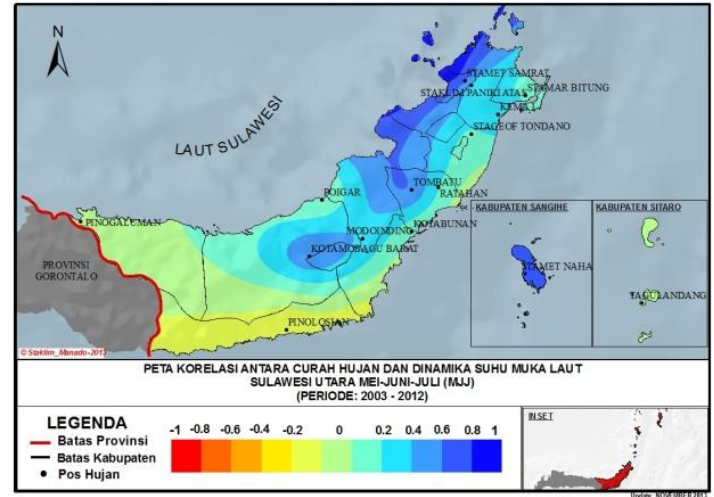

(b)

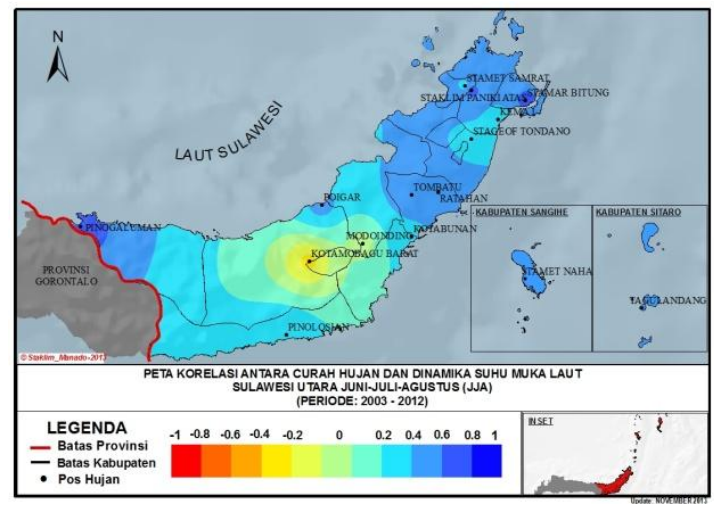

(c) 


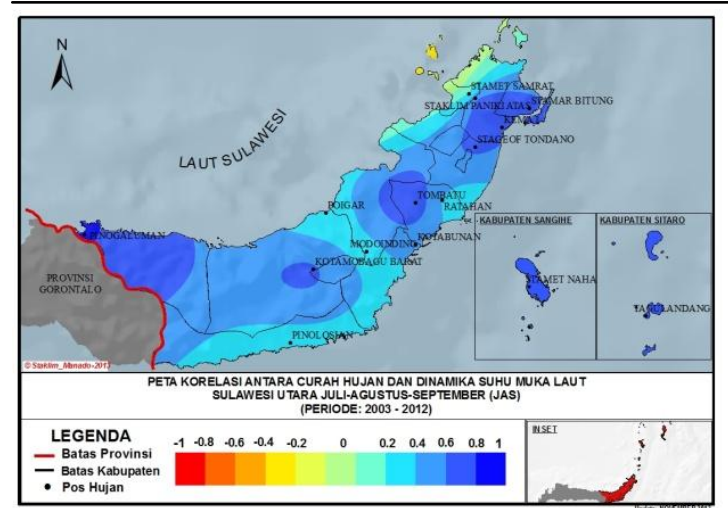

(d)

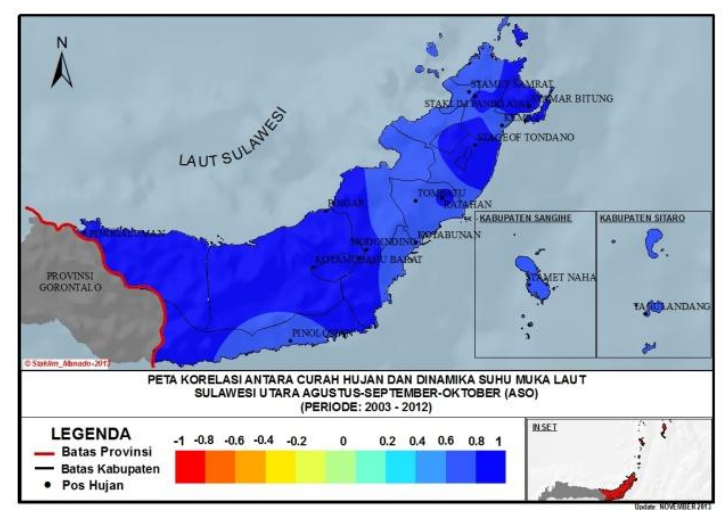

(e)

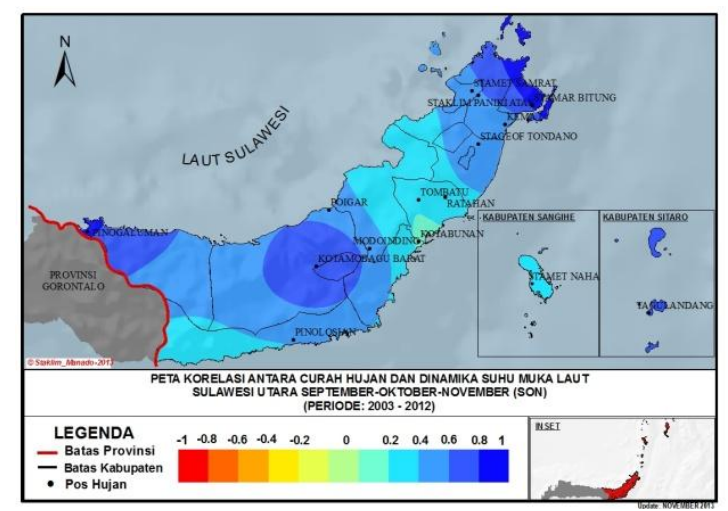

(f)

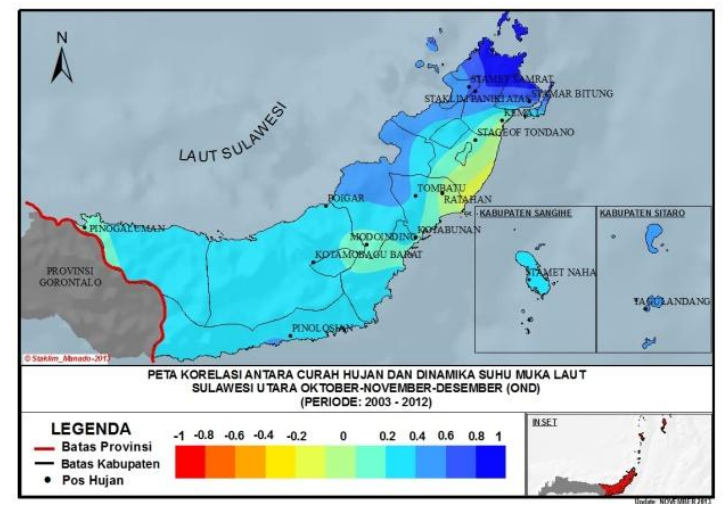

(g)

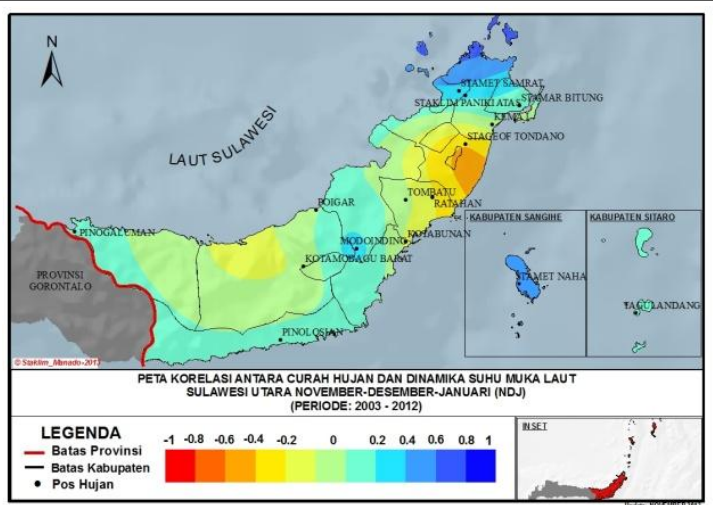

(h)

Gambar 2. Peta Spasial Korelasi Curah Hujan dan Dinamika Suhu Muka Laut (a) AMJ, (b) MJJ, (c) JJA, (d) JAS, (e) ASO, (f) SON, (g) OND, (h) NDJ periode $20013-2012$.

Tabel 1. Korelasi Rata-rata Indeks Osilasi Selatan dan Curah Hujan Tiga Bulanan Tahun 2003 - 2012

Korelasi Rata-rata Dinamika Suhu Muka Laut dan Curah Hujan \begin{tabular}{|c|c|c|c|c|c|c|c|c|c|c|c|}
\hline DJF & JFM & FMA & MAM & AMJ & MJJ & JJA & JAS & ASO & SON & OND & NDJ \\
\hline 0,33 & 0,38 & 0,27 & 0,28 & 0,42 & 0,23 & 0,40 & 0,54 & 0,75 & 0,51 & 0,29 & 0,08 \\
\hline
\end{tabular} \begin{tabular}{|l|l|l|l|l|l|l|l|l|l|l|l|}
\hline 0,33 & 0,38 & 0,27 & 0,28 & 0,42 & 0,23 & 0,40 & 0,54 & 0,75 & 0,51 & 0,29 & 0,08 \\
\hline
\end{tabular}

a. Pada bulan dengan nilai korelasi rendah hingga sangat rendah menunjukkan dinamika suhu muka laut berpengaruh sangat kecil pada distribusi curah hujan. Ada faktor lain yang lebih dominan berpengaruh pada distribusi curah hujan. Nilai korelasi sangat rendah hingga rendah terjadi pada bulan Oktober hingga Maret (periode OND, NDJ, DJF, JFM, FMA, MAM), dan Mei (periode MJJ).

b. Pada bulan dengan nilai korelasi sedang menunjukkan dinamika suhu muka laut cukup berpengaruh terhadap distribusi curah hujan disamping beberapa faktor lain yang juga cukup berpengaruh terhadap distribusi curah hujan. Nilai korelasi sedang terjadi pada bulan April, Juni, Juli, dan September (periode AMJ, JJA, JAS, dan SON).

c. Pada bulan dengan nilai korelasi tinggi menunjukkan dinamika suhu muka laut sangat berpengaruh terhadap distribusi curah hujan. Perubahan suhu muka laut di wilayah Pasifik timur akan langsung membawa dampak terhadap curah hujan di Sulawesi Utara. Faktor lain kurang berpengaruh terhadap distribusi curah hujan. Nilai korelasi tinggi atau positif mendekati 1 secara umum terjadi pada bulan Agustus atau periode ASO (Agustus-SeptemberOktober).

\section{Kesimpulan}

Telah dilakukan analisis pengaruh dinamika suhu muka laut terhadap curah hujan dan diperoleh hasil bahwa:

1. Curah hujan di Sulawesi Utara dipengaruhi oleh dinamika suhu muka laut secara signifikan pada 
periode Agustus-September-Oktober. Nilai koefisien korelasi pada periode bulan tersebut adalah 0,86 dengan kriteria sangat tinggi, dan nilai koefisien determinasi 0,746 atau 74,6 persen faktor dinamika suhu muka laut yang berpengaruh terhadap distribusi curah hujan pada periode Agustus-September-Oktober, dan sisanya dipengaruhi oleh faktor-faktor yang lain.

2. Wilayah - wilayah yang sangat dipengaruhi oleh dinamika suhu muka laut dengan nilai korelasi tinggi, umumnya yang berada dekat dengan pantai. Wilayah - wilayah tersebut adalah Bitung, Naha, Kema I, Poigar, Pinolosian, Pinogaluman, Tagulandang.

\section{Daftar Pustaka}

[1] Aldrian, E., Mimin K., \& Budiman. 2011. Adaptasi dan Mitigasi Perubahan Iklim di
Indonesia. Pusat Perubahan Iklim dan Kualitas Udara. Kedeputian Bidang Klimatologi BMKG, JakartaKartasapoetra, G.A. 1986. Klimatologi. P T. Bina Aksara. Jakarta.

[2] Soepangkat. 1994. Pengantar Meteorologi. Akademi Meteorologi dan Geofisika, Jakarta.

[3] Tjasyono, BHK. 1999. Meteorologi Indonesia. Vol. II, Badan Meteorologi dan Geofisika, Jakarta.

[4] Priyatno, Duwi. 2013. Mandiri Belajar Analisis Data Dengan SPSS. MediaKom, Yogyakarta.

[5] Widiyanto, Mikha A. 2013. Statistika Terapan, Konsep Dan Aplikasi SPSS. Elex Media Komputindo, Jakarta Chatfield, C.1995. The Analysis of Time Series An Introduction. Chapman \& Hall. New York. 